\title{
Sustainability and the megacities: the Gato Park Housing Complex in São Paulo, Brazil
}

\author{
L. Medrano, J. R. Spinelli \& A. R. Bertuccelli \\ Civil Engineering, Architecture and Urbanism School, \\ Universidade Estadual de Campinas - UNICAMP, Brazil
}

\begin{abstract}
The city of São Paulo, with approximately 20 million inhabitants, is a megacity. Its accelerated growth requires the development of architectonic and urban solutions in the rate of its transformations. Social Interest Homes (SIH) constitute one of the most apparent problems of this metropolis, a problem that for decades had as an alternative the construction of large housing complexes or occupations on the outskirts, generally occupying green areas or water sources. Another alternative has recently been tried for SIH - compact occupation in central areas. These new proposals confer power on actions that combat the partial neglect of the infrastructure existing in central areas, including their historical and cultural potential. Urban management in effect between the years 2000 and 2004 idealised public policies that sought to make resources available for the urbanisation of slums, producing verticalised buildings in the places where the latter were to be found. The urbanisation of the Gato slum (Favela do Gato), in São Paulo, with the creation of the Gato Park Housing Complex, is an example of these actions. The intention of the present article is to analyse this project, taking into account new concepts in collective social housing and sustainable development.
\end{abstract}

Keywords: housing in central areas, sustainability, megacities.

\section{Reurbanisation of urban centres and sustainability}

The rehabilitation of urban centres, principally those of big cities, has been a widely discussed subject in the last few decades - if the real city used to be a constraint on modernising ideals of planning, it is today a fundamental 
instrument in post-industrial (or post-modern) urban strategies. The historically, physically and socially constituted network augments the data of a formerly simplified equation. In the understanding of contemporary cities an urban form or urban landscape isolated from its representations in time no longer exists. Moreover, the optimisation of the existing urban infrastructure and the incentive for the configuration of more compact and efficient cities, are fundamental instruments in the sustainable development of today's cities, especially the big cities and megacities of countries in development. Because of the sizes of their cities, large nations such as China, India and Brazil have become a world question - the prompt urban and architectonic decisions of these human megaagglomerations can influence global environmental questions [1].

From the Second World War onward, the great world metropolises underwent continuous and predatory processes of rise and fall in the value of their centres that fragmented and dissolved the existing urban network, altering their symbolic referential character and gradually dissolving their sentimental value. Urban expansion, which took place with greater intensity after the fifties, intensified the process of degradation and neglect of the central areas, replacing commercial functions with less profitable activities and their inhabitants with a population of lesser purchasing power. Out of a perception of urban decline in the central areas of big cities arose the first ideas of urban intervention in the sixties. The processes that follow are classified by Vargas and Castilho [2] in three periods: Urban Renovation, Urban Preservation and Urban Reinvention. The first, Urban Renovation, gives preference to the new and follows the precepts of the Athens Charter and modern tabula rasa urbanism - examples of this period are European reconstructions after the Second World War and the urban renewal processes applied to American cities - Philadelphia, Boston and Seattle. Urban Preservation, which began in 1970, contemplates programmes that reinforced the importance of a constructed patrimony as a symbolic reference of identity and civic pride, and are influenced by the new urbanism of Jane Jacobs, contrary to the modern urban renovation - examples are the cities of Paris, London (Docklands) and Salvador (recuperation of the Pelourinho area). This second period encountered its decline in the nineties, followed by the period that has predominated up till now, that of Urban Reinvention, which comprehends the city on the basis of the reflexes of changes in society and technology, of new modes of production and the globalised economy. It is during this latest period that interventions have been made in American and European cities that have influenced new concepts related to urban actions in central areas, including those in Brazil.

In this process it should be noted that the seventies are fundamental for understanding the Brazilian case. In Europe, the USA and many other countries, "modernist" urban theories have been the target of a series of criticisms, marked by the ill success of ideas of social reconstruction, that have culminated in the decline of the modern movement in theory and in practice. Such criticisms have been aimed at the resulting lack of urban dynamics and have exposed the negative results of the achievements: the new buildings remain empty and the expulsion of residents from the central areas has led to what was subsequently 
called gentrification [3-5]. The dissolution of urban centres has had consequences in various world metropolises: the abandonment of housing in central areas, the degradation and deterioration of public spaces and patrimony in the form of buildings, urban violence, social and spatial marginalisation, building speculation and significant damage to the environment.

Also from the seventies onward, certain theses prepared by critics of the modern movement have sought to alter the principal current architectonic and urban paradigms. Outstanding among them are the well-known books Death and life of great American cities [6] and The architecture of the city [7]. In spite of the new ideas of Jacobs and Rossi, the direct result of these interventions did not succeed in configuring more democratic cities. The principal interventions deriving from these theories were isolated and controlled by an elite minority, which emphasised the importance of historical and architectonic patrimony as a symbol of collective identity and civic pride [8,9]. The implantation of these interventions focused on different results: the realisation of major undertakings that allied culture to consumption and were frequently financed by private initiatives; the concept of urban policies to contain the advance of deterioration by means of the insertion of housing; the improvement of transport and public paces; the encouragement of small businesses and of shared management (or what is called public-private partnership) $[8,2]$. Nevertheless, the result of this process was the creation of scenarios of an urban rehabilitation that never took place. The main consequences were the privatisation of public spaces and the slow expulsion of commerce and local occupants. Among these consequences, Arantes [9] highlights the start of the process of gentrification and the transformation of urban centres into scenarios of an everyday life that is "well polished, clean, decorated and transformed into a museum of itself" [10].

\subsection{Urban reinvention in Brazil}

Judging by the contemporary literature consulted on the subject, it is a consensus of opinion that strategies of intervention cannot accompany a single predetermined model. The so-called local conditionings have already been mentioned by various authors as being fundamental for success in today's urban interventions $[9,11-15]$, an idea that runs counter to modernistic planning theories ("tabula rasa", plan theory, international style etc.) and is based on the pressing questions of contemporary cities. According to authors such as Ascher [11] or Borja [12], although similarities may be found is various urban centres brought about by an emerging modernity influenced by parameters of attractiveness of world metropolises - it is on the basis of their differences that a sustainable intervention project should be founded and developed. To this end, the importance stands out of recognising the real city, the fruit of the disparity between town planning and modernisation, utilising for this purpose projects that confer urban quality and infrastructure on it, as well as city planning instruments for its legalisation [16].

These proposals for interventions, which consider the consolidated city, its culture and history, would, as we have seen, contradict the more orthodox concepts of the Modern Movement related to cities and their evolution - a key 
essential for understanding the process of town planning in Brazil (from Brasília to municipal master plans). Modern town planning has ignored the forms of the past in the name of the construction of a new society. Belief in social transformation and architecture as an instrument for the reorganisation of space presupposes the need to liquidate the past, making it ever emptier of meaning, and the extraordinary valorisation of novelty.

In Brazil, one of the best-known alternatives to predominant modernistic planning is found in the projects for requalification of the historical centralities that propose to encourage local social diversity. Starting from the perception of the degradation of urban centres and their structural possibilities, various projects have been undertaken in cities such as Rio de Janeiro, Porto Alegre and Salvador, focusing on questions such as tourism, cultural facilities, historical patrimony, public spaces and housing. In São Paulo, the city that constitutes the object of this study, an important process of Urban Reinvention was begun in the nineties, its main basis being the reorganisation of the social geography of the central region by means of public policies of inclusion, such as the building of Social Interest Homes (SIH). From this period onward, certain public administrations have prepared initiatives created for the benefit of the low income populations that live, circulate or work in the central region.

\section{Public policies and Social Interest Homes in São Paulo}

Between the years 2001 and 2004, the central region was presented as one of the political priorities of the municipal authorities of the city. A plan, known as "Reconstructing the Centre", was displayed for the area that received support from the private sector of the state government (sic). Among its guidelines was that of expanding residential use and guaranteeing the diversity of functions, as well as encouraging town planning actions with social inclusion.

Within the period some initiatives were taken for the adoption of public policies suitable for making the balanced reoccupation of the centre feasible: such initiatives respect the undeniable vocation of the central region, as historical and cultural patrimony encourages its occupation by sectors of municipal and state administration, including the transfer to the centre of various secretariats, as well as the city hall itself, but take into consideration the need of its consonance with the residential sector of different social classes. With this in mind, the Live in the Centre programme is one of the most comprehensive actions in the period - it seeks to integrate in one and the same set of strategies diverse technical and political mechanisms directed towards housing facilities of social interest. Live in the Centre is subdivided into three sub-programmes: the Residential Rental Programme (RRP), the Social Location Programme and the Integrated Habitat Rehabilitation Programme (IHRP), all of them making use of the public financing system. According to the data of the City Hall, by January 2004 more than 1,200 families had already been benefited by this set of programmes [17]. Outstanding in the Social Location Programme, a great innovation in the municipal scenario, is the Gato Park (the former Gato slum), with 270 residential units. 


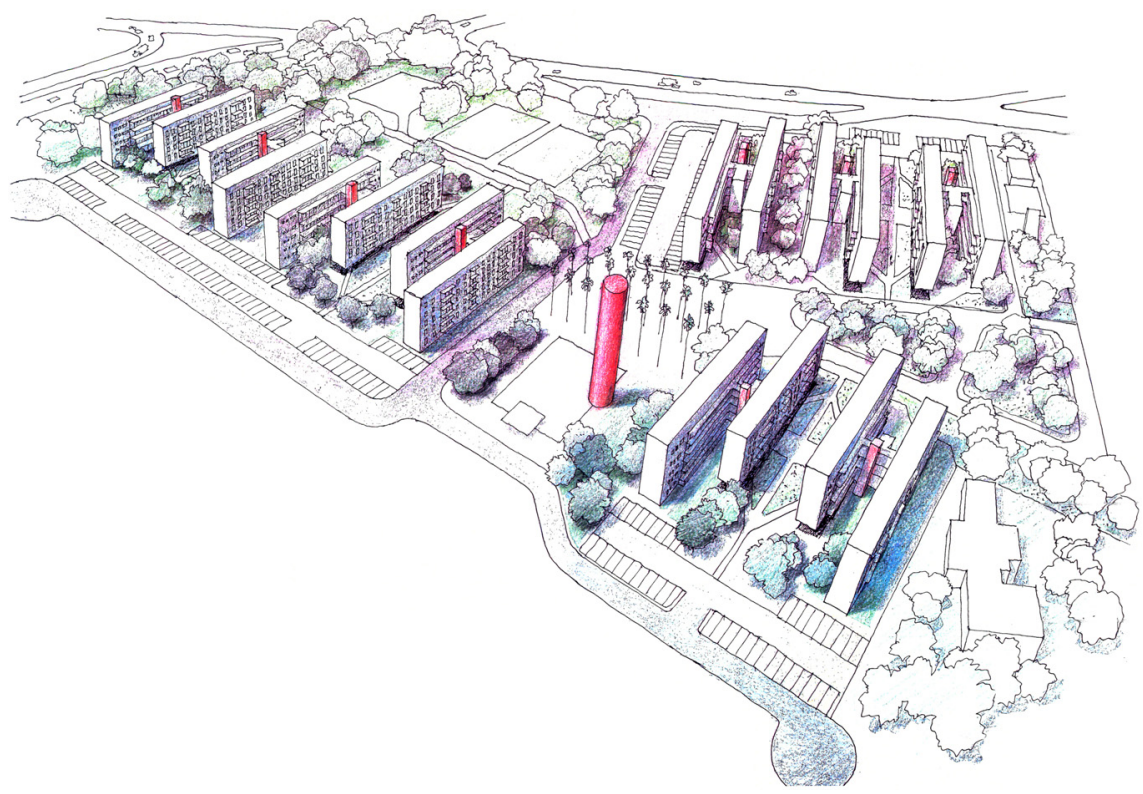

Figure 1: $\quad$ Perspective (drawing) (Peabiru Trabalhos Comunitários).

\section{Gato Residential Park Project}

\subsection{Programme}

The Gato Residential Park is situated in the district of Bom Retiro, in the central area of São Paulo. Besides the housing units, the complex includes a linear park, a day nursery and a garbage recycling facility.

What was there before the launching of the project was the Gato Slum, a 1.5 $\mathrm{km}$ long stretch of shacks and huts on stilts on the banks of the River Tamanduateí. After twelve years of existence and miscellaneous aggravating events, such as floods and fires, the municipal authorities of São Paulo decided on the urbanisation of the slum on the lines of the Social Location Programme. 120 of the 396 families resident in the slum were removed to lodgings while awaiting the building of the park. The others remained where they were.

Budgeted at $\mathrm{R} \$ 24$ million, the park was built with resources coming from the São Paulo Municipal Housing Fund and partially with a loan from the InterAmerican Development Bank (IDB). The Social Location Programme benefits people with an income of between one and three minimum wages and, in the case of Gato Park, the rent corresponds to $10 \%$ of monthly income, around R $\$$ 30,00 for the average family, discounting expenditure on water and electricity.

The site has a total area of $175,000 \mathrm{~m}^{2}, 52,000 \mathrm{~m}^{2}$ of which are intended for the residential sector, in the eastern part of the project area (housing plus park). With a built up area of $28,603,73 \mathrm{~m}^{2}$, it has sports facilities, free areas, a playground, gatehouse and parking lot, work having begun in September 2003. There are 
nine five-storey blocks (ground floor plus four other floors), each with 54 flats (twelve flats per upper floor and units adapted for the handicapped on the ground floor). The six ground floor units adapted for the handicapped correspond to $11 \%$ of the number of units, above the legal standard, which requires $3 \%$. In addition to the ground floor units, the kitchenette type units can also be adapted, with the installation of handholds. Each block of flats is formed of two identical mirrorimage "slabs", $6.80 \mathrm{~m}$ out of alignment, interlinked by a vertical circulation box and a metal walkway. The ground storeys in one of the block buildings have a meeting area, with the adapted units in the other. Established in four condominiums (known as 100, 280, 40 and 120), they comply with legislation, having a "non edificandi" belt of 50m from the crest of the slope of the bank of the River Tamanduateí and of $15 \mathrm{~m}$ from the rear face towards the Avenida Presidente Castelo Branco. Three of the condominiums have two blocks, totalling 128 units, and one has three blocks, totalling 162 units, making a grand total of 486 flats, 270 of which were handed over in July 2004 and 216 in December 2004.

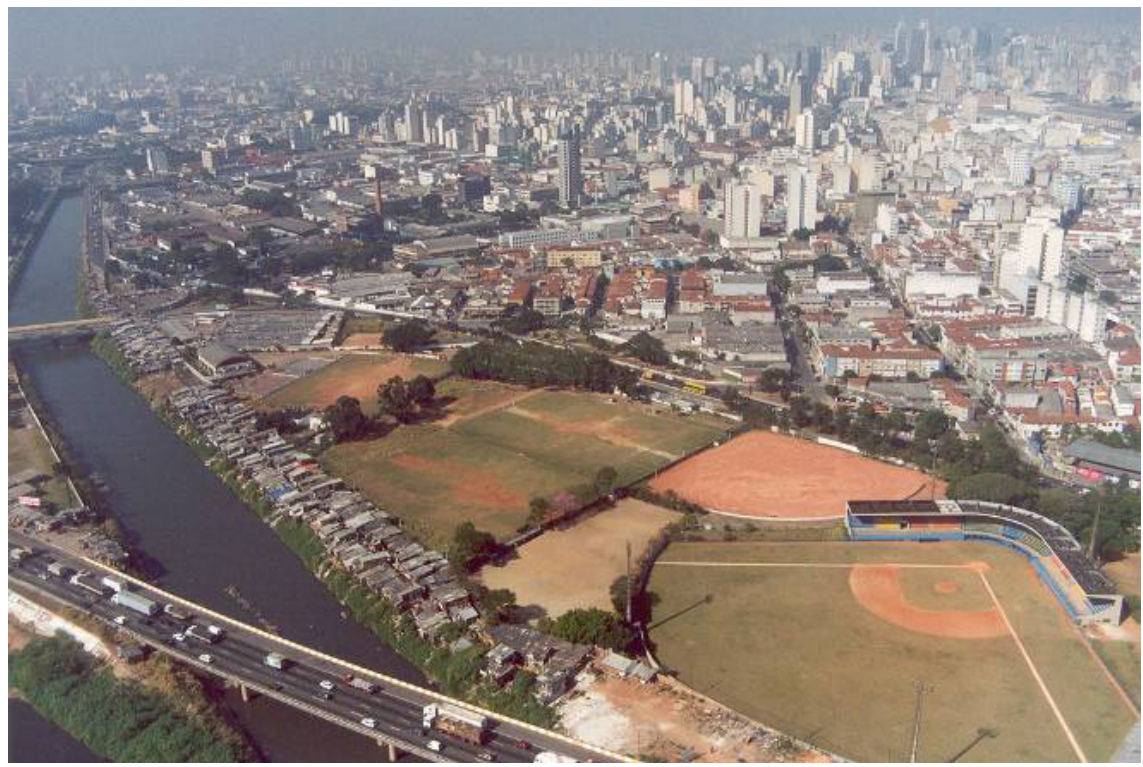

Figure 2: Aerial view, before the construction of the project (Peabiru Trabalhos Comunitários).

\subsection{Implantation}

The terrain is practically even, with subtle variations of level maintained from the stage of implantation onward. The is a public thoroughfare of dovetailed concrete blocks that crosses the site transversally and divides it into two "arms" without an exit for vehicles, giving access to the condominium lots and 
institutional area. Entry is from the Av. Presidente Castelo Branco and exit by means of an interlink with the express way, the stretch being controlled by traffic lights.

In accordance with the Project, the public areas are distributed in three parts: a green area with a $33 \mathrm{~m}$ tall water tower supplying the site and giving it an urban character; another area facing the district, with trees planted in an endeavour to avoid grime coming from the avenue; facilities such as a multi-sports court, a skate rink and a playground, of which only the playground has been built. It is possible for pedestrians to cross to the banks of the River Tamanduateí, since this green area borders the condominium lots, forming a grove. The projected commercial centre building is of modular type and is planned to comprise a newsstand, a chemist's shop, bakery and establishments for the use of the district. This has not been built. The buildings are grouped in pairs or in threes in the condominiums and the limits of the lots are irregular, which, according to the aide-mémoire, emphasises the breaking of alignment of the block slabs, which could be lost in rectangular or square lots. The raised ground storeys are faced, creating a level square covered by the projection of the buildings. Gardens and coloured details advance below the projections to contrast with the rationality of the blocks.

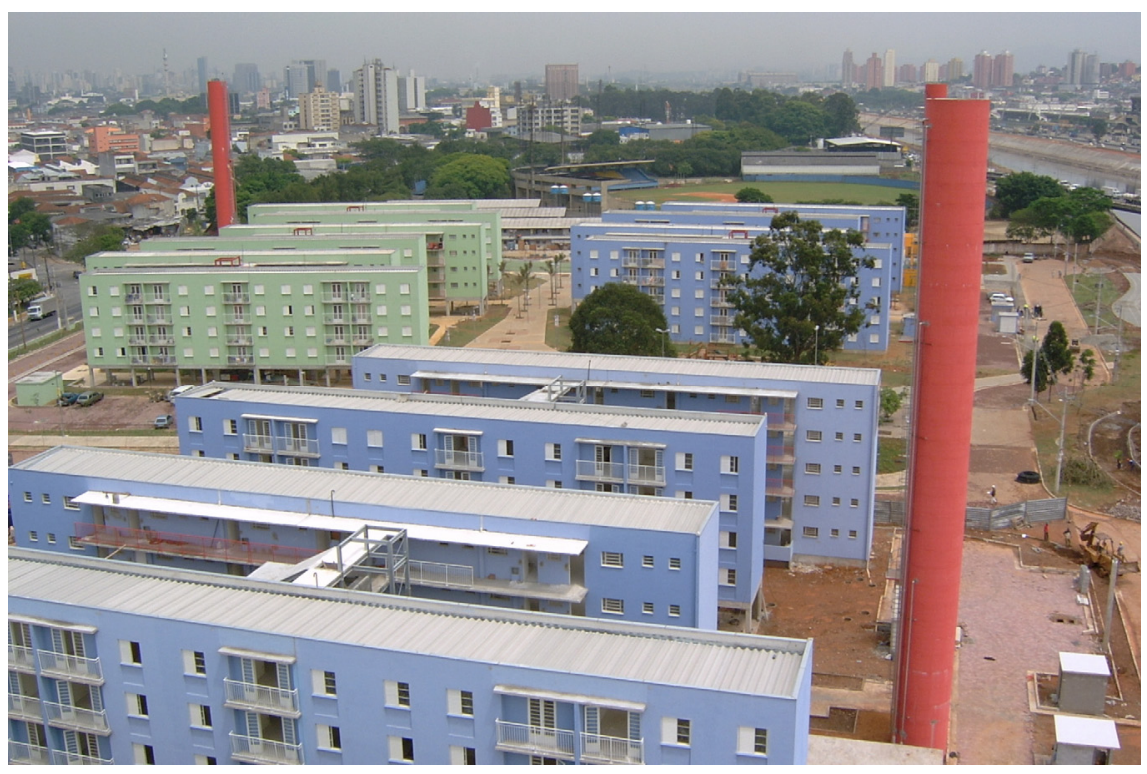

Figure 3: View of the housing blocks in Gato Residential Park (Peabiru Trabalhos Comunitários).

\subsection{Occupant profile and present situation}

A large number of the occupants of the Gato Park (almost 90\%) come from the Gato slum. Families are made up of three or four persons, 39.61\% of whom are 
engaged in informal employment. There are 122 cases of families living in irregular circumstances, i.e. the occupants are not among the original applicants as per the rental contract, invasions and internal exchanges of flats having occurred.

In a survey made by Cohab in $2006,50 \%$ of the occupants said that they made no use of the common areas. The level of satisfaction of the occupants of the complex, however, was about $90 \%$ (occupants who gave top marks on a scale of zero to ten).

The rental system does not confer the right of ownership of the dwelling but, thanks to a symbolic rent, allows a minimum income worker to live with more dignity. Nevertheless, this has not prevented certain occupants from engaging in property transactions, frustrating the mechanism of feasibility of the project. The articulation of urban projects with municipal management is fundamental for town planning in areas that constitute an example of inequality, such as tenements and slums, and for making feasible those urban practices that seek to resolve them.

\section{Conclusions}

The Gato Park project seeks to consolidate a hypothesis of the centre as an environment of cultural and social diversity, and thus one economically and environmentally more sustainable. It is a clear intention expressed in the public policies on which the project is based - seeking to reveal new forms of housing consonant with the emerging necessities of the São Paulo metropolis. Forms that are distinct from foreign models almost never adequate for the local context, but also innovatory in relation to our own modern tradition, at once responsible for the greatest criticisms of the sector. Both the great modernistic housing complexes of the outskirts and disorderly occupation in the central areas (slums) constitute one of the greatest obstacles to the sustainability of the constructed environment of the city of São Paulo.

Nevertheless, despite the conceptual advances that have permitted the establishment of the Gato Park complex, its architecture still maintains manifest links with the planning concepts of the Modern Movement. Parallel blocks, pervaded by a "park", configure a scenario of exception to the existing city - a result in conflict with its primary intentions of integration within the local historical network.

This being so, correlation between (national and international) theoretical bases related to Social Interest Homes situated in central areas and the object analysed give priority to certain considerations:

1. The need of a widening of theoretical debate between architects and town planners on the subjects of contemporary architecture and sustainability (architectonic, urban and social), principally on the relationship between the project and its importance as an articulating element of the polis.

2. Greater participation between urban plans and architectonic interventions, i.e. an articulation between plan and design so that the results reflect their intentions in a coherent manner. 
3. Updating of studies of contemporary urban housing typology. Thinking of the reurbanisation of central areas without a greater association with the design and form of these interventions may, as we have seen, impair their results and expectations.

\section{Acknowledgement}

Thanks are expressed to FAPESP (Fundação de Amparo à Pesquisa do Estado de São Paulo - São Paulo State Foundation for the Support of Research), for help in the preparation of this article.

\section{References}

[1] Larsson, N. An Overview of Green and Sustainable Building in 2006. Second Megacities Conference Proceedings, Guangzhou, 2006.

[2] Vargas, H. C. \& Castilho, A. L. H. (orgs.). Intervenções em centros urbanos - Objetivos, estratégias e resultados, Manole: Barueri, 2006.

[3] Glass, R. Introduction to London: Aspects of Change. Center for Urban Studies: London, 1963.

[4] Smith, N. Toward a theory of gentrification: a back to the city movement by capital, not people. Journal of the American Planning Association, v.45, p. 538-548, 1979.

[5] Bidou-Zachariasen, C. De volta à cidade - Dos processos de gentrificação às políticas de "revitalização" dos centros urbanos. Annablume: São Paulo, 2006.

[6] Jacobs, J. The Death and Life of Great American Cities. Vintage: London 1961

[7] Rossi, A. A Arquitetura da Cidade. Martins Fontes: São Paulo, 1966.

[8] Arantes, O. B. F. Urbanismo em Fim de Linha. Edusp: São Paulo, 1998.

[9] Arantes, O. B. F. A Cidade do Pensamento Único: desmanchando consenso. Vozes: Petrópolis, 2000.

[10] Arantes, O. B. F. A Cidade do Pensamento Único: desmanchando consenso. Vozes: Petrópolis, pp 126, 2000.

[11] Ascher, F. Metropolização e transformação dos centros das cidades. Os centros das metrópoles: Reflexões e propostas para a cidade democrática do século XXI. Imprensa Oficial do Estado: São Paulo, pp 59-68, 2001.

[12] Borja, J. Urbanização e centralidade. Os centros das metrópoles: Reflexões e propostas para a cidade democrática do século XXI. Imprensa Oficial do Estado: São Paulo, pp 69-73, 2001.

[13] Borja, J. Grandes projetos metropolitanos: mobilidade e centralidade. Os Centros das Metrópoles. Terceiro Nome, Viva o Centro \& Imprensa Oficial do Estado: São Paulo, 2001b.

[14] Castells, M. A questão urbana. Paz e Terra: São Paulo, 1983.

[15] Meyer, R. M. P. O espaço da vida coletiva. Os centros das metrópoles: Reflexões e propostas para a cidade democrática do século XXI. Imprensa Oficial do Estado: São Paulo, 2001. 
74 Sustainable Development and Planning IV, Vol. 1

[16] Grimberg, E. (org.). Jordi Borja [interview] Publicações Pólis, São Paulo, v. 16, p. 15-25, 1994.

[17] Urbs Magazine. São Paulo, p. 24, 2004. 